\title{
Teacher Knowledge on Student and Its Relation with Teching and Learning Process
}

\author{
Mohd Aderi Che Noh
}

\begin{abstract}
Knowledge on students is needed for teachers so that they can provide the appropriate teaching and learning that meet the needs of every student as they come with differing backgrounds and culture. These differences should be noted to ensure that the strategies, approaches, methods and techniques selected are able to represent all ethnic groups in the class. Therefore, this study explores teachers' knowledge on students, especially the socio-economic and socio-cultural aspects of students. Qualitative research design was used in this case study which involved four teachers of Islamic education in Sarawak via purposive sampling. Data were analyzed thematically using the Atlas. ti7. 1. 7software. The results showed participants in the study have the initiative to find out the background of the students, especially the economic and cultural aspects of students. Knowledge about both these aspects helps them in conveying the teaching of Islam. The results also indicate that the socio-economic and family culture can have positive and negative implications for the students' learning processes in the classroom. Hopefully, these findings provide a paradigm shift for teachers of Islamic education in creating meaningful lessons for students.
\end{abstract}

Keywords: knowledge on students, cultural diversity, Islamic education, socio-economic, socio-cultural

\section{INTRODUCTION}

Apart from delivering the content of the subject being taught, the teacher has a role in knowing who their students are. Knowledge on students is necessary to help teachers choose strategies, approaches, methods and techniques used in delivering content of the lesson. Knowledge on these students include aspects related to the background, level of maturity, cognitive level, the level of understanding, preparedness, intelligence and differences found among them including the characteristics that they possess. Knowledge of students is necessary so that the teacher can use the appropriate strategies, approaches, methods and techniques that can meet the needs of entrepreneurship students based on their different backgrounds. The selection of teaching methodologies, including appropriate teaching materials will assist teachers in understanding the students, as well as to make the learning process enjoyable thus leaving a positive impact in the students. This is also consistent with the distribution of cognitive levels in determining the learning outcomes to be achieved, so teachers must be sensitive to these different groups.

\section{KNOWLEDGE ON STUDENT}

At the implementation stage of the teaching process, teachers should have the teaching skills, including the skills on the social worlds of their students. This includes the students' backgrounds, socio-economic status and socio-cultural elements. According to Azizi Yahya et al. (2005), socio-economic status also determines whether the physiological needs of pupils are met or not. For low income families, educational opportunities might be slimmer than the pupils whose families have high income. The same goes for the influence of community and students' socio-cultural background. The community, which consists of a variety of cultures and attitudes, has a different and distinctive way of life. This influence is vital in the evolution process of the school children because it can affect and change significantly if the students do not get basic nurturing of strong common values.

This opinion is in line with Abdullah Ishak (1989), which stated that the effectiveness of teaching and learning is not only dependent on the charisma, intellect, personality and maturity of a teacher, but it depends also on how well a teacher knows the students' background such as the student's family, mental, physical, cultural characteristics and inclinations. The need to take cognizance of the students' family, community, nation and cultural background has been discussed by Muslim scholars such as Ibn Sha'ban (1997), Ibn Khaldun (2000) and Abdullah Ishak (1989), and Sharifah Alwiah (1988). This is because the knowledge of these matters will enable teachers to interact effectively in their relationships in the classroom and during the process of teaching and learning. It is also because the duties and responsibilities of teachers do not stop 
in the classroom, in addition, they also need to discuss and communicate with parents so that the growth of students can be informed through the relationship. Contact and discussions will also help and support the teaching process.

The importance of discussion and communication in relationships between teachers and parents is also fundamental to teachers in selecting appropriate approaches in their teaching. In terms of the cultural diversity that exists in the classroom, teachers need to avoid boredom and confusion by choosing approaches and methods that can celebrate the students who come from diverse cultural, language, practice, beliefs, race, and dialects as well as cultural sensitivity. Therefore, Islamic Education teachers should be sensitive to these diversities. This is because the students are different in their attitudes toward other groups, which are not their own group. In fact, there are students who are very ethnocentric and treat people who are different from themselves in terms of race, colour, economic status, religion and values as inferior, whilst some other students consider the other person as unique and distinctive and are able to see the similarities between themselves and others, and appreciate and accept the different attributes (Sharifah Alwiah Alsagoff, 1988).

The Prophet PBUH highly celebrated every individual's differences in learning whether those who received the calling through da'wah or those who asked (Abu Ghuddah, 2009). He interacted with each individual based on the person's understanding and appropriate to their position. He also took care of the feelings of the new student, which the Prophet PBUH did not teach them what is being taught to those who has been studying for a long time. He answered the questions raised, based on the person's interest and situation.

Therefore, a teacher of Islamic education (GPI), which simultaneously acts as a preacher, should have in depth knowledge of the students. Through knowledge of the these students either in terms of the students' backgrounds, socio-economic and socio-cultural details, teachers will be able to identify the problems faced by the students, it is easier for them to lend a hand, build the potential of students and boost the students excellence in academics as well as character. Knowledge on students who come from various backgrounds, different ethnicity and race will also help teachers to provide guidance and attention to them.

This is because these students have different needs and requirements, and it is the responsibility of each teacher to meet these different requirements. This diversity of needs and requirements will lead to the diversity of learning styles which in turn gives implications for the process of teaching in Islamic Education.

\section{THE TEACHING OF ISLAMIC EDUCATION}

Teaching is a process that encompasses the activities of planning, implementation, evaluation and feedback. It aims to disseminate knowledge or skills. The function of teaching is to produce effective learning, a person that is well-adjusted and harmonious, knowledgeable and honourable. Thus a good learning session should involve the skills of teachers in matching the teaching methods to the learning objectives and learning styles of their students (Shahabuddin Hashim et al., 2003).

Meanwhile, learning is a mental, physical or spiritual activity to the students themselves. It is a process where individuals can change their attitudes and behaviour to grow continuously and consistently and is able to use the knowledge and skills acquired for the development of themselves in particular and society or the nation in general. Thus learning occurs when there is a change in behaviour, thoughts, perceptions and affective including feelings, attitudes and values (Shahabuddin Hashim et al., 2003).

In the context of Islamic education, the teaching and learning of this subject should look into the purpose of Islamic education itself as stated by Hassan Langgulung (1980), the process of preparing the younger generation to fulfil their role, transfer of knowledge, Islamic values are aligned with the function of man to do good in the world and reap the rewards in the hereafter. Through the process of teaching and learning of Islamic education, the individual student will be formed, guided spiritually and physically to be an Islamic personality and able to prepare them better in facing the surrounding community (D. Marimba, 1980).

Hence, curriculum development in general or Islamic Education in particular, will not be complete and perfect if teaching and learning methods are not given emphasis (Ismail Ibrahim et al., 2011). The acquisition of knowledge and the development of a perfect personality are not only due to the charisma and personality of the teacher, but also due to a curriculum that is complete and supported by a broad range of teaching methods. The effectiveness of teaching and learning of Islamic education also includes a few things namely motivation, needs and interests of students, ensuring the 
learning objectives, determining the level of maturity of the students, knowing the individual differences, observing their comprehension, integration of existing knowledge with the original, and making the process of education as an experience that delights students (Azyumardi Azra, 2012).

However, the Cabinet Committee report (1979) to review the implementation of the education policy, found that the practice of teaching and learning of Islamic education is still of a low quality (Ministry of Education 1988). Similarly, Mohd Aderi (2008) also found that instructional practices of teachers in Malaysia are still at a moderate level. Teachers are still found to be using simple or old approaches (chalk and talk), the approach of delivering information to the students in one way only. Approaches that use teaching aids and practical assignments are less practiced (Muhamad Suhaimi, 2008), in other words, learning strategies are more focused and centred on the teacher.

By examining the above issues, it is clear that these teachers are still using teacher-centred approach, while in reality the use of such strategy is not able to meet the diverse needs of the students. This is because in the teaching of Islamic Education we cannot deny the existence of multiple levels of achievement, a variety of backgrounds and cultures brought by the students into the classroom. Hence it is the responsibility of the Islamic Education teachers to meet the diverse needs of the students so that education can be fairly given to them.

\section{THE PRACTICE OF TEACHING OF ISLAMIC EDUCATION BASED ON CULTURAL DIVERSITY}

The Quran states that the Prophet Muhammad P. B. U. H. was a great teacher and educator throughout the ages. As Allah the Almighty stated in Surah Al-Jumu'ah 62:2 which means

"It is He who has sent among the unlettered a Messenger from themselves reciting to them His verses and purifying them and teaching them the Book and wisdom - although they were before in clear error."

\section{(Abdullah Basmeh 2011)}

In carrying out education of the companions, the Prophet highly celebrated the distinction of each individual who learns whether those who were given the da'wah or those who inquires (Abu Guddah, 2009). He interacts with each individual based on his understanding and in line with his position. He also takes care of the feelings of people who are just beginning to learn, where the Prophet did not teach them what is taught to those who have been learning for a long time. He answered the questions posed based on the interests and circumstances of the person. Here it shows that although he strongly encourages people to go for jihad and migrate, but in this case he looks at the situation and the ability of the companions and the situations of the people who are asking. Sayyidina Abdullah bin 'Amr bin Al-As said: a man came to the Prophet, who then said:

"I gave the oath of allegiance to you for emigration and to wage jihad in order to get the reward of Allah. The Prophet said: Are any among your parents still alive? Yes, in fact they both are: the man replied. The Prophet said: Do you want the reward of Allah? The answer is: Yes! The Prophet continues by saying: Go home to your parents and serve them."

(Sahih Sunan An-Nasa'i, Kitab al-Jihad, 3103; Sahih Sunan Tirmidhi, Kitab al-Jihad, 1671)

Based on the above hadith, it is clear to us that he really took into account individual differences and needs while imparting knowledge or advice. The use of his method or celebrating the diversity of students as used by the Prophet P. B. U. H. is applicable in implementing the values of cultural diversity in the teaching of Islam and this has made the teaching of the Messenger effective on the companions.

The same goes to the effectiveness of teaching and learning of Islamic Education which includes motivation, needs and interests of students, ensure learning objectives, identify the level of maturity of the students, knowing the individual differences, observing the understanding, integration of existing knowledge with the origin, and the process of education as a pleasing experience for students (Maimun Aqsa Abdin Lubis et al., 2013). In the teaching of Islamic Education based on cultural diversity, the culture of the school should be driven to make the elements of culture such as values, symbols, beliefs and norms are supported and cultivated and inserted incidentally in the teaching (Federal School Inspectorate, 1993).

Atan (1980) has highlighted three important aspects in shaping the effectiveness of a teacher, which is the teachers' personality, knowledge background on the lessons to be taught and the methods or means of delivery. Meanwhile, AlShaibani (1979) argues that the concept of teaching and learning is a good method to help students acquire the knowledge, 
skills and to change attitudes and behaviour and also to instil the desired values. Teachers are also suggested to deliver lessons in accordance with the level of students' level of thinking (Al-Shaibani, 1979; Al-Ghazali, 1988; Ibn Khaldun 2000). Usually the existing skills and knowledge of students will become blurred and more complicated if the teacher delivers a lesson without any advance regardless to the level of students' thoughts and achievements.

In the context of the teaching of Islam, cultural diversity based instruction is a perspective and a strategy to understand the culture of students of various races and cultures in the class. Teaching based on cultural diversity is needed to help students understand the diversity of cultures in the country and they are directly involved in teaching and learning. The aim of education should be able to bring awareness to students about the existence of different cultures and language in the community and that there exists similarities in culture and language variety (Asmah Haji Omar, 1992). Mastery of the mother tongue for example, help students avoid using a language without violating the norms or rules of language that has been set by a society that uses the language. Thus a more harmonious relationship can be created during the interaction.

According to Banks (2001), education based on cultural diversity is a concept or idea related to beliefs, admission and recognition of diversity and the diversity of cultures and ethnicities that exist that affect the lifestyle, social experience and personal identity of a nation. Multicultural education aims to: (1) develop an understanding of other cultures, (2) shape attitudes towards cultural and racial diversity, and (3) a process to learn new experiences about the values and culture of others. Banks $(2001 ; 2005)$, states that multi-cultural education from a variety of programmes, courses and practices carried out by educators are responses to the needs, desires and aspirations of various groups. These include gender, nationality, age, gender, marital status, race, ethnicity, social class, religion and culture.

Based on the above discussion, the teaching of Islamic Education based on students' cultural diversity can be illustrated by Figure 1.1 below:

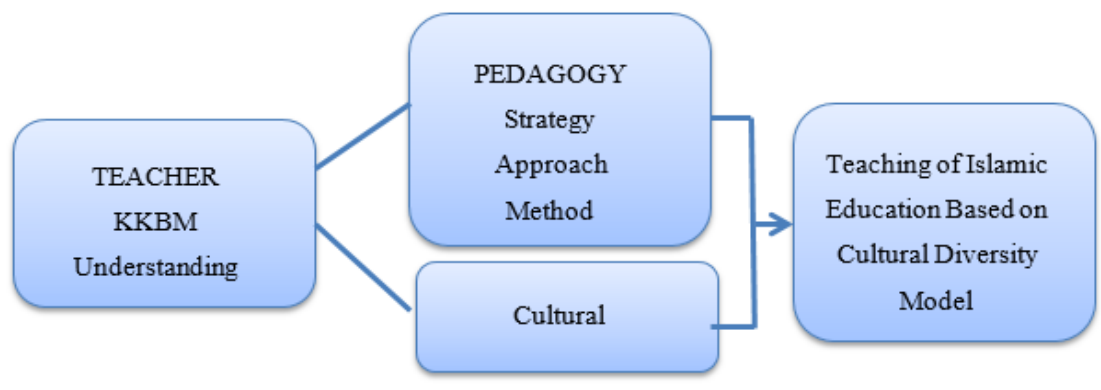

Figure 1. 1: The practice of teaching of Islamic Education Based on Cultural Diversity

In terms of its importance, educational system which based on the cultural diversity is important for a developing country with a multiracial population. This step can shape and create a united people, to create and maintain the identity of the country and improve the quality of life and spirituality of the humanity as a whole. Lewis (1994) pointed out that an understanding of the culture of other ethnic groups will increase tolerance. This will make one more inclined to practice the values accepted by society. At the same time, one would know and understand more cultures.

Ibn Khaldun (2000) also explains that, in order to see the civilization of a nation, one must refer to the nation's culture, including elements of the language, lifestyle, religion and habits of dressing and practiced values. While acknowledging the existence of the tribe or nation in human society, Islam recognizes the existence of varying cultures and ways of life. According to Ismail Hamid (1996), some jurists argued that urf (custom) for a nation that does not conflict with the legislation can be considered as a source of law that was not already explained by the Quran and Hadith.

Education on cultural diversity is not only meets the requirements of Islam as in Surah Hujurat 49:13, but can also achieve the National Education Philosophy. Education on cultural diversity is also compatible with the Islamic concept of the issues related to ethnic relations. This is because, multi-cultural education views mankind as a macro and micro creature thus tied to each culture and ethnicity (Rina Hanipah Muslimah, 2010). Islam has always provided a procedure on relationships between Muslims and non-Muslims based on a solid, sturdy and tidy foundation which include tolerance, justice, charity and compassion that has never been seen in human history before Islam. 


\section{THE CONCEPT OF CULTURAL DIVERSITY IN THE TEACHING OF ISLAMIC EDUCATION}

Religion is the basis of culture and cultural practices, while faith is the foundation of religion. Therefore, faith, religion and culture can be summed up as a union called the Islamic ad-din. Although culture comprises of relationships between humans can be differentiated with religion, which is a relationship with Allah the Almighty, these two cannot be separated. Ibn Khaldun (2000) also pointed out that, in order to see the civilization of a people, we should refer to the nation's culture including elements of language, way of life, religion and dressing habits as well as values that are practiced. In addition to acknowledging the existence of tribes or race in human society, Islam recognizes the existence of varying cultures and ways of life. In fact, some jurists are of the opinion that the urf (custom) of a nation that does not conflict with the Islamic law can be considered as a source of law that is not explained by the Quran and the Hadith (Ismail Hamid, 1996).

Sociologists explain the cultural variations of the two approaches, i. e. functionalism and ecological. The functionalism approach analyses the components of culture in terms of the functions of those components to determine the social order as a whole. According to this theory, culture and society are mutually dependent on each other. Some elements of culture cannot be separated by the entire social system and culture as a whole. Concurrently, the ecology approach also sees culture as one way to adapt to the environment. Thus, the cultural practices of a community are closely linked to its environmental opportunities (Sharifah Alwiah, 1988). It is a fact that the school plays a role as an agent of cultural transmission, and without an agent it is difficult to expand the culture of a generation (Hussein, 1993).

This view is consistent with the view of sociologists Nik Safiah (1985), and Mohd Taib (1988), which also describes the birth of a culture as coming from the energy of the mind, spiritual effort or the energy of moving the soul to meet its biological and social needs and can be adapted to its surroundings. Through these efforts, the formation of thoughts, beliefs, opinions and habits are ultimately inherited and determine the behaviour of a society. Cultural behaviour can be studied through three indicators, namely; (i) language, (ii) religion and belief and (3) the inherited customs (Ahmad Man, 2005). These are the indicators that according to him assert ethnic identity and display the unique characteristics.

Based on the discussion of the background of the study, this study was carried out to fulfil the objectives and answer the following research questions:

\section{RESEARCH OBJECTIVES}

Exploring teachers' knowledge of the students in a multicultural classroom.

\section{RESEARCH METHODOLOGY}

This study used a qualitative approach using a case study design. Qualitative methods are used for this study because it is very suitable in reviewing a case in an in depth and comprehensive manner (Slavin, 1992) and in gathering information about a case. In addition, qualitative methods can provide an opportunity for researchers to observe and examine the participants' knowledge on the real study environment of the students (Merriam, 1998). Creswell (1988) put forward several reasons for choosing a qualitative approach. Among them, because (i) the nature of the research questions that need answers on how and what had happened, (ii) the exploratory title of the research, (iii) research that requires detailed observations, and (iii) the qualitative approach emphasises the researcher as the main instrument who can tell the story from the perspective of non-participants or emic perspective as opposed to etic perspective (Merriam, 1998). Researchers had information based on what actually happened in the classroom. Data was collected by using interviews and direct observation of the teaching sessions.

The sample selection is done using purposive sampling by Miles \& Huberman (1994). Study participants had to be selected and identified in advance so that he can give appropriate and adequate information. In this study, a total of four Outstanding Teacher of Islamic Education (DG44) subject at SMK Sarawak State were selected in this study. Selection of study participants went through a screening process through the Islamic and Moral Education Sector of the Sarawak State Education Department and they have volunteered to participate in the study. Data was analysed in a thematic manner and organised using Atlas. ti 7.1.7 software.

\section{RESEARCH FINDINGS AND DISCUSSION}

The data obtained were coded as in Table 1. 0.

Table 1. 0: List of Codes, Categories and Themes

\begin{tabular}{lll}
\hline Code & Category & Themes
\end{tabular}




\begin{tabular}{ll}
\hline & Knowledge On Students \\
\hline PTM- SE & Socio-economic \\
\hline PTM- SB & Socio-cultural \\
\hline
\end{tabular}

\section{KNOWLEDGE ON STUDENTS' SOCIO-ECONOMIC ASPECT}

After analysis and coding, emerging research themes found that nearly all research participants agreed that some of the themes of knowledge on the students can be categorised into several aspects of general information such as the level of socio-economy of the students.

Based on the research findings, research participants indicated that, in implementing teaching based on cultural diversity, Islamic Education teachers have knowledge of the socio-economic status of their students. This knowledge on the socioeconomic level is necessary because economic factors influence discipline and academic achievement of a student. According to Fatima and Badri, in their school, they found that the students which have good economic backgrounds tend to have good discipline and academic achievement as compared to the students who are from low-income families.

This point is illustrated by the following interview; "If we do research here in this school, if the economic background of the family is ok, the discipline of the student is ok, usually his academic is also ok, I suppose he might have made his parents as his idol? Ok, then if we were to look at the students in the last class, if the parents are labourers, perhaps he/she will be less motivated". For these students, they also seem to think that education is a matter of no importance. This is stated in the following interview; "For them it is like... in themselves there is no realisation... education is not seen as important".

Ustazah Fatimah also linked socio-economic background of the students with the students' motivation to learn. According to her; "We must see if his/her parents are labourers, perhaps he/she is less motivated" (Ustazah Fatimah). Ustazah Fatimah's statement is also supported by Ustaz Badri who is also clarified that the socio-economic level of the students indeed highly influences the culture of their attitudes. According to him, students who come from the poorest households will have humility due to their meagre condition and they are also lacking of adequate school supplies. This is his explanation; "Socio-economic background indeed influenced the culture and the attitude of the students, some have low self-esteem... while studying. Why? They don't have enough. Only has a pen, school uniform not ironed, and all. They are lacking in supplies". In the situation that the students are not motivated, the Islamic education teachers need to have an approach to motivate them.

Meanwhile, for Noor, she also agrees that teachers should have the knowledge of their students' condition including their socio-economic background. Based on her observations at the school, she found that students, who come from families with relatively low economic situation, will be lethargic when at school. Hence in this case, the teacher should first investigate why the students are in such a situation and not punish them at will. This was stated by her through the following quote; "If he comes to school, and he is weak and so on, for us I cannot immediately scold him. Perhaps he did not eat right? Parents might have no money to cook food for breakfast. This is usually the case... Need to really... ", and according to Badri; "Most of the students having learning difficulties in this study are those who are under privileged". This is stated in following quote; "...coming to school, bus fares have to be sourced on their own. Finally, they seem to give up".

Badri and Noor both agree that the economic background of the students is also related to their discipline. Students who come from families with financial difficulties will cause problems at school such as coming late to school and truancy. This is explained by the following interview; "He has discipline problems, and such... who violate the school rules, arrived late at school", "most of the troubled students in this study are the ones facing relatively difficult lives... ". For Noor, it is difficult for families whose parents are busy working and do not give attention to the application of Islamic values or education, it will have an impact on students' achievement and their acceptance of Islamic education compared to families who do not 
have economic problems. This is her explanation; "Certainly has an impact. Compared to students whose family gave attention on anything related to Islamic education, when we teach, they are easier and faster to receive".

\section{STUDENTS' SOCIO-CULTURAL ASPECT}

Apart from knowledge on the socio-economic background of the students, participants of this study also felt that teachers also need to know their students socio-cultural backgrounds. Knowledge of the socio-cultural background of the students is greatly needed as there are those among the students who are unclear and do not understand the true teachings of Islam. This problem occurs especially among students with a background of a family who has newly converted to Islam. This was stated by Noor through the interview as follows; "There are students who converted to Islam who are very unclear of the teachings. It seems that they do not understand at all. When asked, owh, the family has converted to Islam!". This is because the family has just embraced Islam but is still not practicing Islam such as fasting and not fasting.

In the situations like this, the teacher should teach according to the level of ability and the aptitude of the students and ensure that all lessons are in the syllabus. Effective teachers will group the students based on their ability and mastery of a certain skill. Cognitive level based teaching approach is acknowledged especially for the students who are new converts. This is admitted by Noor in the following interview; "I just know that there are Muslim converts, which family did not practice, I can say it is not a direct practice. No prayer, no fasting, right? If I can touch her feelings, she is like, she is interested".

Also, in such situations, teachers need to apply touching the feeling approach to them. The use of this method is to make the students interested in the teaching of Islamic education. This socio-cultural knowledge can help teachers provide examples relating to their experiences at home either in terms of practices and ways of life, where the teacher can use a significant approach to the students so that they can more easily understand the day's lessons.

For Hamni, she stated that knowledge on socio-cultural of the students is needed so that teachers can give examples and relate to what is taught during the day with the events in their lives. Teachers' knowledge about who their students are, their siblings, race, family, and what revolves around them can help them in dealing with those students. This is because the practice of their parents at home has implications for the practice and appreciation of the students' knowledge and skills that they have learned in school. This is expressed through the following interview; "...culture will influence them indirectly and brought to school".

Hamni also stated that there are among parents of students who do not fast, causing some students who are not fasting while in school. But what delighted her is that there are those among the students who fasted but did not take the pre-dawn meal until it causes them to be weak and sleepy while studying in the classroom. This was stated by her through the following quote; "I have had a student who, during the month of fasting, were weak... at 8, 9, 10 am and sleepy. I wondered why? No pre-dawn meal. But he fasted, best of all he fasted. I wondered why do you not take the pre-dawn meal? Mother does not fast, father does not fast. Haa, that's a fact".

Based on the findings above, there are two major components related to teachers' knowledge on students in a multi-cultural class, which are: the socio-economic and socio-cultural backgrounds of students. This is illustrated by Figure 1 below:

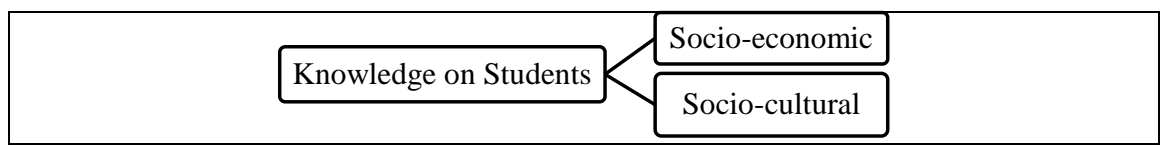

Figure 1: Knowledge of Teachers on Students

\section{DISCUSSION}

Knowledge of the students have been discussed in previous writings and is an important component in the production of quality teaching (Shulman, 1986, 1987; Ibn Khaldun, 2000; Aintley \& Luntley, 2007; Coombs, 2009; Kamarul Azmi, 2010). Based on the findings of this study, it is indicated that participants of the study have the knowledge of the socio-economic and socio-cultural backgrounds of their students. This finding supports the findings of Ahmad Yunus (2011) which states that GCPIs are knowledgeable and sensitive to the diversity of the students' characteristics. This has led to the selection of methods and techniques which are appropriate to the students in the teaching of Islamic Education. 
The research findings showed that teachers provide a special biodata form for each student who was taught. This is indicating their determination to know more about their students. The findings are consistent with the views of Coombs (2009) that the use of a brief profile of the students can help teachers to become more familiar with the background, progress and specific needs of a student. Therefore, it is highly important for the Islamic education teachers to realise that the classrooms they teach are filled by a variety of students who wish for recognition as individuals, are called by their names and have distinctive requirements that must be met.

Teaching of Islamic Education should also be coordinated with the students' level of thought and their knowledge. Furthermore, the Prophet PBUH himself was very concerned with the aspects of individual differences in the delivery of his teaching (Abu Ghuddah, 2009). Similarly, in implementing multicultural education in the teaching of Islamic Education, the Subject teachers need to have knowledge about the diverse backgrounds of students in the classroom to determine the suitability of the subject matter and methods which are used in the teaching and learning. Selection of subject matter and appropriate teaching methods will facilitate teachers in implementing the teaching and learning process. This is consistent with the study of Ahmad Yunus (2010) in which students must also be understood in the context of their different background, past knowledge and readiness of mind to help teachers implement their treatment and delivery of teaching materials effectively. Consideration of the diversity of this difference provides an opportunity for practical learning experiences to students (al-Syaibani, 1991).

Socio-cultural knowledge also helps the teacher to know who their students are and so that they can use the examples close to the students and as a way for teachers to facilitate their coexistence with the local community. Students' interest can also be nurtured and developed if teachers take into account the socio-cultural differences of students because there are students who do not practice what they have learned in the classroom due to lack of encouragement at home. It is these groups' interests that should be enhanced as well as their motivation to learn so that they are keen to learn and teachers will do not simply punish them if they do not practice what they have learned. This is in line with Kamarudin (2006) who stated that the teaching which is not consistent with the cognitive level of the student and acceptance will create boredom among students. The Prophet PBUH as a leading teacher also took into account individual differences in the educational and enlightenment processes (Abu Ghuddah, 2009).

Specific knowledge relating to the students allows the Islamic Education teacher to determine the selection of teaching materials and approaches, as well as appropriate and effective methods and techniques in the teaching of Islamic Education. Teachers' relevant knowledge of the students will enable content knowledge held by the teacher to be adapted to suit the students and delivered to the target accurately and effectively. Thus, the ability and knowledge of teachers on pupils' socio-cultural and socio-economic background assist teachers in selecting materials, methods and techniques appropriate when implementing the teaching of Islamic Education, especially in the classroom which consists of various cultures.

\section{CONCLUSION}

The socio-economic background of students that are retained in the minds of teachers indirectly facilitates the planning of quality teaching, thus attracting the students' interests as well as increasing their level of motivation. Concurrently, knowledge about the students' socioculture connects the teachers with the local community lifestyle and will shape the teaching of Islam in multicultural classes with the descriptions and examples of the variety of different ethnic groups. Ultimately, the goal of the creation of man from various race and ethnicity (syucuban wa qabailalitacarafu) is indirectly achieved in the teaching of Islam in a multicultural classroom.

\section{References}

[1] Abdullah Ishak. 1989. Sejarah Perkembangan Pelajaran dan Pendidikan Islam. Petaling Jaya: Al-Rahmaniah. 
[2] Abu Ghuddah. 2009. Rasulullah Pendidik Terulung: 40 Teknik Mengajar Rasulullah. Ter. j Hj Shuhadak Mahmud. Negeri Sembilan: Al-Azhar Media.

[3] Ahmad D. Marimba. 1980. Pengantar Filsafat Pendidikan Islam. Al-Ma'arif. Bandung.

[4] Ahmad Man. 2005. Pengajian Malaysia: Kenegaraan Dan Kewargenegaraan. Kuala Lumpur: Prentice Hall

[5] Al-Quran al-Karim. Tafsir pimpinan Ar-Rahman kepada pengertian al-Quran: (30 juz). Ed. Ke 12. Kuala Lumpur: Darulfikir.

[6] Al-Syaibani, Omar Muhammad Al Toumy. 1991. Falsafah Pendidikan Islam. Shah Alam: Hizbi

[7] Azizi Yahya, Asmah Suboh. 2005. Aplikasi Kognitif Dalam Pendidikan. Kuala Lumpur: PTS Profesional

[8] Azyumardi Azra. 2012. Pendidikan Islam Tradisi dan Modernisasi di Tengah Tantangan Milenium III. Kencana Prenada Media Group. Jakarta.

[9] Hassan Langgulung. 1980. Beberapa Pemikiran tentang Pendidikan Islam. Al-Ma'arif. Bandung

[10] Ibn Khaldun. 2000. Mukaddimah Ibn Khaldun Terj. Dewan Bahasa Dan Pustaka Malaysia. Kuala Lumpur: Kementerian Pendidikan Malaysia.

[11] Ismail Hamid. 1996. Pengajian Kebudayaan Melayu Dari Perspektif Islam: Satu Perbincangan Awal. DIm. Wan Hashim Wan Teh \& Mahayudin Yahaya (pnyt). Sains Sosial Dari Perspektif Islam. Bangi: Universiti Kebangsaan Malaysia

[12] Ismail Ibrahim, Mohd Yusof Hj Othman. 2011. Laporan Penyelidikan Keberkesanan Pendidikan Islam Dalam Pendidikan Kebangsaan. Universiti Kebangsaan Malaysia.

[13] Kamaruddin Hj Abu Hassan. 2006. Penerapan Nilai Islam Bersepadu Dalam Model Reka Bentuk Perisian Multimedia Pendidikan Geografi Tingkatan 6. Tesis Dr. Fal, Fakulti Pendidikan, Universiti Kebangsaan Malaysai.

[14] Merriam, S. B. 1998. Qualitative Research and Case Study Applications in Education. San Francisco: JosseyBass.

[15] Miles, M. B. \& Huberman, A. M. 1994. Qualitative Data Analysis. 2. Thousand Oak California: Sage Publication.

[16] Mohd. Aderi Che Noh. 2008. Hubungan Antara Amalan Pengajaran Guru Dan Pencapaian Tilawah Al-Quran Murid Tingkatan Dua Di Malaysia. Tesis Fakulti Pendidikan, Universiti Kebangsaan Malaysia.

[17] Shahabuddin Hashim, Rohizani Yaakub. 2003. Pedagogi Strategi Dan Teknik Mengajar Dengan Berkesan. Pahang Darul Makmur: PTS Publication \& Distributors Sdn. Bhd.

[18] Sharifah Alwiah Al-Sagoff. 1988. Psikologi Pendidikan 1 Konsep-Konsep Asas Psikologi Dan Psikologi Pendidikan, Psikologi Perkembangan. Petaling Jaya: Longman Malaysia Sdn. Bhd.

[19] Slavin, R. 1992. Research Method in Education (2 ${ }^{\text {nd }}$ edition). Boston: Allyn and Bacon.

[20] Suhaimi Muhamad. 2008. Tahap Kesediaan Guru Terhadap Pelaksanaan Model Pengajaran Simulasi Bagi Mata Pelajaran Pendidikan Islam. Tesis Sarjana Pendidikan, Universiti Teknologi Mara. 